\title{
The Great Ārdrā Darśanam Festival: Performing Śaiva Ritual Texts in Contemporary Chidambaram
}

\section{Aleksandra Wenta}

International Journal of Hindu Studies

ISSN 1022-4556

Volume 17

Number 3

Hindu Studies (2014) 17:371-398

DOI 10.1007/s11407-014-9148-8

\section{International Journal of \\ HINDU STUDIES}

Edited by

Sushil Mittal

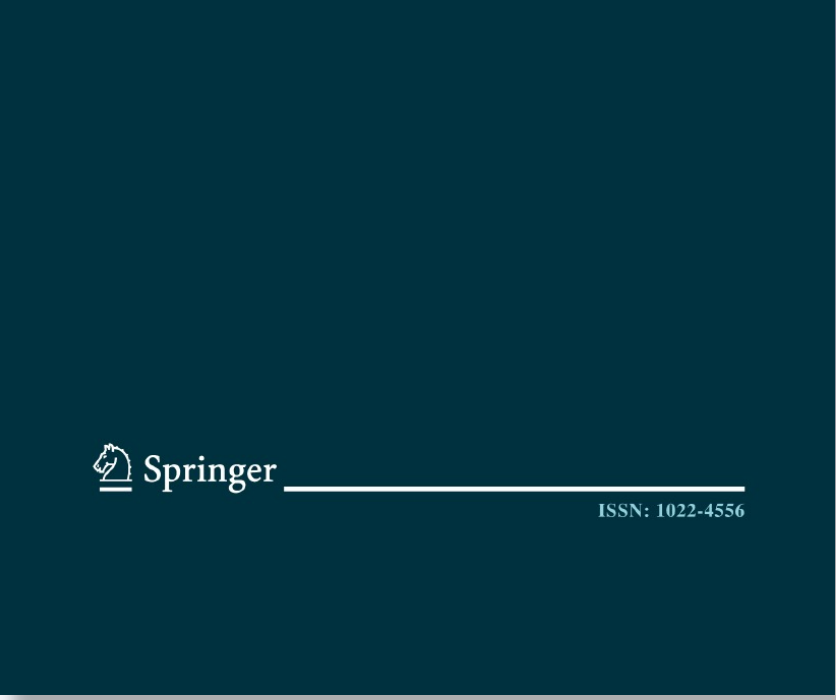

Springer 
Your article is protected by copyright and all rights are held exclusively by Springer Science +Business Media Dordrecht. This e-offprint is for personal use only and shall not be selfarchived in electronic repositories. If you wish to self-archive your article, please use the accepted manuscript version for posting on your own website. You may further deposit the accepted manuscript version in any repository, provided it is only made publicly available 12 months after official publication or later and provided acknowledgement is given to the original source of publication and a link is inserted to the published article on Springer's website. The link must be accompanied by the following text: "The final publication is available at link.springer.com". 


\section{The Great Ārdrā Darśanam Festival: \\ Performing Śaiva Ritual Texts in Contemporary Chidambaram}

\section{Aleksandra Wenta}

The annual Ārdrā Darśanam Festival (Mahotsava in Sanskrit, Tiruvāturai in Tamil) is held at Chidambaram in honor of the Ārdrā star. ${ }^{1}$ It falls during the longest night of the year, in the Tamil month of Mārkali (December/ January). The festival, which is one of the two foremost events of the year (the other, called Āni, taking place in June/July), is believed to commemorate Śiva's birthday in his form of Națarāja, the "King of Dancers."

The Chidambaram festival lies at the threshold of two great Indic textual cultures: the "southern" Tamil tradition and the "northern" Sanskritic tradition, each of which bring to the festive space their own performative value. The northern Sanskritic tradition is mainly represented by the Citsabheśotsavasūtra, an undated "Vedic" prescriptive manual of the festival ceremony attributed to the mythological sage Patañjali. The southern Tamil tradition is represented by the Tiruvempāvai, a bhakti hymn of the ninth-century saint-poet Mānikkavācakar. These two texts offer a framework that sets the terms for customary festival practice in contemporary Chidambaram. On the occasion of this festival, they seem to exist side by side and become embodied in performance.

The Ārdrā Darśanam Mahotsava provides an interesting example of entanglement not only between Sanskrit and Tamil textual traditions, but also between "textuality" and "performance"-which have crystalized into the categories of "past" and "present," respectively. To disentangle the interlaced threads of the texts' multifaceted structure would require

International Journal of Hindu Studies 17, 3: 371-398

(C) 2014 Springer

DOI 10.1007/s11407-014-9148-8 
several years of research; what I will provide here is a preliminary account outlining the festival practice in contemporary Chidambaram, which will serve as an initial attempt to understand the phenomenon of the Chidambaram festival in its full complexity. My main interest is to make some reflections on the consistencies and inconsistencies between the "prescribed" and the "performed" that I detected through textual research and fieldwork. By describing the re-enactment of key elements featured in the prescriptive texts that shape the festival performance, this paper attempts to explore aspects connected with crucial questions-partly addressed by previous scholars ${ }^{2}$-around the relationship between the written (prescriptive) and the performative (enacted) dimensions, namely: to what extent are the Sanskrit texts from the past still relevant to the Śaiva religiosity as practiced in contemporary Chidambaram? What role, if any, do these manuals play in the performances of temple rituals and festivals? Why are certain scripturally prescribed elements implemented in the festival scenario while others are totally abrogated?

The originality of this paper lies in making the relationship between the "textual" and the "performed" explicit by highlighting an aspect of textual authenticity, which underpins elements of historical continuity of the sacred festival practice. Such an approach to the study of festival practice in contemporary Chidambaram has not been undertaken so far. The only available account of the festival practice in present-day Chidambaram is given by Paul Younger (1995: 46-77), who provides an elegant and informative description of the two major festivals from the anthropologist's perspective. Because of his anthropological focus, Younger's "picture" of the festival practice lacks proper textual dimension that actually drives and justifies all enactments of festival celebration. My paper incorporates this "lost" textual dimension and presents the "text" as a legitimate source of the festival practice rather than a superfluous addition.

\section{Ārdrā Darśanam Mahotsava: Interface Between Textuality and Practice}

In recent years, there has been a considerable shift in the conceptualization of textual traditions through the adoption of a more anthropological, performance-oriented approach to the study of written texts stemming 
from different cultures, geographical locations, and historical periods. As Richard Bauman points out, textuality is not merely a literary artifact, but also a mode of communicative practice in which a "performer must give shape to the [textual] utterance anew and mark it as performance in the real-time unfolding of actual events" (2012: 103). This performative dimension ascribed to the text comes into being through the practical process of rendering the textual fabric into the field of action. By freeing itself from the shackles of discourse, the text finds itself in a concrete situational context, that is, in the event of action.

The Sanskritic world, with its astonishingly rich literary traditions, has always been aware of the inextricably intertwined relationship existing between "text" (śāstra) and its "practical implementation" (prayoga). As Sheldon Pollock (1985: 504) argues, the extent to which śāstra and prayoga are linked together is such that any attempt to separate these two would be futile. Pollock further argues that the intricate relation between śāstra and prayoga, when understood in terms of "the actual enactment of the knowledge," sets up a single standard of rationality in Indic cultural practices. Basing his argument largely on specific examples from different textual materials, he shows how the descriptive character of saastric "knowing that" becomes necessary furnished with prayoga-the prescriptive core of "knowing how."

The first glimmerings of this longstanding association of textuality with praxis appear prominently at the very beginning of the Citsabheśotsavasūtra, which explicitly identifies itself as the navadinotsavaprayoga, or "nine-day festival praxis." 3 Such a statement shows how the practical aspect is deeply ingrained in the textual fabric, postulating inbuilt fluidity between the two. On the other hand, the normative implications of prayoga are clearly visible in the text, whose internal structure rests basically upon the series of festival injunctions (vidhi). The vast array of vidhis, whose semantics is articulated by such notions as rule, ordinance, command, precept, and so on, points towards the authoritative character of scripturally prescribed elements that must be implemented in the festival scenario.

Historically, the confluence of prayoga and vidhi, or "performative" and "prescriptive," coming together in the body of the text resulted in the creation of a new literary genre of utsavavidhis, or "festival manuals." This process gained momentum in Cōla Chidambaram. The Citsabheśotsava- 
sūtra, although of uncertain authorship and date of compilation, clearly belongs to the same literary movement that sought to establish festival as the core cultural practice of Cōla Chidambaram. A comparison between the "Vedic" Citsabheśotsavasūtra of mythological origin and the "Āgamic" Mahotsavavidhi attributed to Aghoraśiva of twelfth century ${ }^{4}$-an "Āgamic" festival ritual text based on the dualist theology of the fully blown Śaiva Siddhānta-is instructive in this connection. A careful investigation of both texts uncovers a large area of commonality that seems to confirm the anthropological observation made by Younger (2002) about the structural uniformities of festival celebrations in the ancient Cōla kingdom that have been preserved to the present time and are enacted even today. In the following section I will reflect upon the specific cultural underpinnings of this particular historical milieu that still resonate with meaning in the contemporary festive space of Chidambaram.

\section{Historicizing the Utsavavidhis}

One way of looking at the utsavavidhis, or "festival manuals," is to see them through the prism of a larger festival cultural practice that rose into prominence during the Cōla reign. All major religious festivals held during the Cōla reign apparently show the influence of local kingship. ${ }^{5}$ The recorded history of that period is found in extensive inscriptions carved on wall tablets in numerous temples. The festivals performed in the temples were directly linked with the personal asterism of the ruler: with either the day of the king's accession or the day of his natal star (see Swaminathan 1978). The historical origins of Ārdrā Darśanam Mahotsava lie in "Ārdrā" - - the natal star of Rājendra Cōla I. The Ārdrā Mahotsava was initially organized in honor of the king as the festival called Rājendra Cōlan Tirunal, or the Sacred Day of Rājendra Cōla. During this festival, drama and dance were performed and the Tiruvempāvai was sung. ${ }^{7}$ The Ārdrā star also happens to be the asterism of Siva Națarāja. Through sharing the same natal star, the identity of the king was connected to that of the deity, and through this connection the king's persona acquired both cosmic and divine identity. Similarly, the second annual Națarāja festival, known as Āni Mahotsava, which is still performed today, was initially associated with the asterism of Uttiraț̣ādi or Uttara Bhādrapāda, the natal star of Vikrama Cōla (Swaminathan 1978: 273). 
The history of Cōla Chidambaram presents us with much evidence for the increment of festival practice during the reign of Vikrama Cōla, who sought to promote the Națarāja temple at Chidambaram — the Cōla "family temple" - as the most important Śaiva center in South India (Harris 2008: 111). According to Richard H. Davis (2010: 19), Vikrama Cōla and his court minister Naralokavīra both sponsored Națarāja festivals by providing lamps on the processional routes, watering the streets during festivals, and donating several bronze icons and ritual processional paraphernalia. The imperial policy of the Cōla dynasty was founded on the idea of divine kingship, which provided a strong affiliation between religious and political spheres. Religious festivals could therefore be seen as a form of political propaganda that, through the powerful display of royal magnificence and sacrality, served the purpose of legitimizing royal power and the divine status of the king at the same time. ${ }^{8}$ The essence of the festival was constituted by a procession of gods mounted atop different vehicles (vāhana), such as a lion and a bull, or on chariots. As Joanne Punzo Waghorne (1999) points out, vāhanas played a vital role in the sociopolitical sphere of medieval Tamilnadu. Vāhanas were inextricably linked to royal presence and power as they had an independent status as royal emblems (Waghorne 1991: 26). ${ }^{9}$ Epigraphic credentials acknowledge the fact that the public processions of gods during these festivals were often accompanied by royal processions. In one such documentation preserved in stone, Vikrama Cōla's visit to Chidambaram is mentioned. ${ }^{10}$ This overtly political dimension of the festival can be thus seen as a rationale for the development of a new cultural practice that evolved simultaneously with the consolidation of forms of a political cult. This cultural practice aimed at strengthening the internal legitimization of royal power within a particular society. As Knut A. Jacobsen points out:

One of the common explanations of the function of Hindu processions in India is that they are statements of devotion that make a claim on territory, the gods circle their realm, which also means the site of the procession is the borderline of their area and is public space that no single deity can claim (2006: 165).

The "claim on territory" pertinent to the procession of gods can be easily extended to the political practices of medieval Cōla Chidambaram. As 
Daud Ali states: "Early medieval kings performed much of their political action through processions. Their conquests were essentially processions around the quarters of the earth" (1996: 187). In this context, festival procession can be viewed as yet another example of religious practice overtly intertwined with political interests based on the idea of a divine kingship. The fluid boundaries between the king and the god were also acknowledged in the field of literary production. Just as the god taken in procession required a specific festival manual, so did the king. The composition of processional poems, known in Tamil as ulās, reached its peak in the twelfth century. Ulās were political texts that advanced the idea of Cōla dominance through procession. The most important figure in this new literary milieu was the court-poet Oțtakkūtar, who composed ulās for three successive generations of Cōla kings: Vikrama, Kulottunga II, and Rājarāja II (Wentworth 2011: 185). Performance of these lyrics extolling royal glory used to accompany kings going in procession.

\section{“Āgamic Śaivism” vis-à-vis "Vedic Śaivism": The Double Identity of Chidambaram Festival Praxis}

An intriguing aspect of the Ārdrā Darśanam Mahotsava is that it provides the sacred ground on which these two contested ritual, doctrinal, and social spheres come to terms with each other. These are the "classic" form of Śaiva Siddhānta-represented by the Sanskritic tradition of Āgamas and utsavavidhis—and the so-called "Vedic Śaivism"—-that is, a Saiddhāntika tradition that sees itself as being closer to, in terms of being the "crème" or essence, rather than the antithesis of the Vedas and by extension of orthodox (smārta) Brāhmanic milieu. ${ }^{11}$

Historically, the "Vedicization" or appropriation of Vedic/mainstream Brāhmanical discourse into Śaiva discourse represents a tendency to move towards or make an alliance with mainstream orthodoxy by the Śaiva Siddhānta, which itself constitutes the "most orthodox" and mainstream of all Śaiva systems. David Smith notes that by the day of Umāpati Śivācārya ${ }^{12}$ the celebrated Śaiva author who flourished in fourteenthcentury South India:

There had been several centuries of development of Śaiva thought, development fostered by royal patronage over much of India. The 
Siddhānta had become an all-embracing system, encompassing temple worship and architecture. There was an increasing readiness on the part of that system to compromise with what was originally the alien thought of the Vedas (1998: 103).

It has been suggested that the Śaiva Siddhānta had developed strategies for coming to terms with Brāhmanical conservative and orthodox forces that were deeply woven within the fabric of South Indian society, especially in view of securing the royal patronage that was vital for its survival. This development seems to have occurred in parallel with another shift in emphasis from individual practice (yogic, ritual or otherwise) to temple rituals. Whereas the earlier strata of the Saiddhāntika corpus focused on individual practice and private worship (both internalized or in form of external rituals) of the sādhakas, or married householders, the later stage of fully blown Āgamas compiled in South India increasingly focused on temple rituals and festivals, carried out exclusively by priestly specialists (ācārya). As claimed by Hélène Brunner (1975-76: 110-14), in both public and private ritual the influence of the Āgamas is real: for instance, a Saiddhāntika manual like Aghoraśiva's paddhati, which is based on the $\bar{A}$ gamic corpus, is followed to the letter by most priests even in modern Tamilnadu. These manuals, however, are eminently, and in most cases exclusively, focused on the practical dimension of ritual and pass over in silence the doctrinal and theological dimension. It is the Āgamas that provide those aspects along with the Śaiva philosophical and ontological basis upon which Śaiva ritual lies.

The entanglement of the Saiddhāntika edifice with particular temples, deities, and cults is a prominent feature of the utsavavidhis. Besides that, an entanglement between "canonical Āgamic" and "Vedic" Smārta elements is especially detectable in the Citsabheśotsavasütra, which constitutes a perfect example of a festival manual comprised of elements from both traditions.

Given what has been just said, it is interesting to observe that the festival practice in Chidambaram was exposed to influences from authoritative scriptures of various communities and owes to both the Saiddhāntika and Vaidika traditions. For instance, some authors (for example, Loud 2004: 7) name the Śaiva Saiddhāntika Makuțāgama as the original scriptural source for the Chidambaram Natarāja festival practice. This view is not 
shared by G. Parameśvara Dīkșita, a priest of the Chidambaram temple who is famous for his scholarship in the Vedas. During an interview held in December 2012, Parameśvara Dỉkșita claimed that Ārdrā Darśanam Mahotsava follows exclusively the Citsabheśotsavasūtra attributed to Patañjali and that the uniqueness of this text lies in its entirely "Vedic" character. Still, he could not avoid admitting that some of the actually performed festival practices prescribed in the Citsabheśotsavasütra are found pervasively in the Saiva Saiddhāntika texts describing festival injunctions, which is at odds with his earlier claim.

Generally, the Chidambaram temple follows Vedic $p \bar{u} j \bar{a}$ codified in the Patañjalipūjāsūtra or the Patañjalipaddhati. Unlike all other Śaiva temples of Tamilnadu, which normally follow Aghoraśiva's Śaiva Saiddhāntika canon, the Națarāja temple of Chidambaram constitutes an example of "Vedic Śaivism," insofar as it traces its ancestry to the mythological figure of Patañjali, the snake-bodied sage whose myth is narrated in the Cidambaramāhātmya (Smith 1998: 31-45) and to whom authorship of the Citsabhesotsavasūtra is attributed. The "Vedic" character of the Citsabheśotsavasūtra is further visible, for example, in its treatment of the Vājapeya sacrifices that must be performed by Dīkșitas (priests of the Chidambaram Națarāja temple) during the festival. However, in some instances, the priests also incorporate Āgamic injunctions into their ritual scenario. This happens especially in regard to the sequence of rules (vidhikrama), the rite of attraction (karșana), ritual establishment (pratișthā), festival order (utsavakrama), and expiatory acts (prāyaścitta) (Loud 2004: 2). Some scripturally prescribed elements narrated in the Citsabheśotsavasütra, such as the ritual installation of breath (prānapratisthāa) that is believed to "animate" icons of the deities ( $m \bar{u} r t i)$, belong to the classical Agamic repertoire. ${ }^{13}$ Perhaps even more important in this regard is the "Festival of Black Paste" (krṣnagandhotsava), also called the "Festival of Dancing Śiva" (nrttamūrtyutsava), a typically Āgamic ritual, which was one of the most commonly celebrated festivals in Saiva temples in Tamilnadu, dating back to perhaps even before the eleventh century. This is performed during the last day of the festival, which symbolizes destruction of the primeval impurity covering the human soul (Nagaswamy 2003: 86).

It has been argued that at some point in history the festival practices of Chidambaram underwent important changes. No doubt, it is significant 
that the double identity of Citsabhesotsavasūtra, comprised of both "Vedic" and "Āgamic" elements, is the one aspect most immediately visible to a careful reader. This observation advocates the historical plausibility of these two distinctive Sanskritic traditions existing side by side in Chidambaram and shaping in their own right the outlook of festival praxis. It may be suggested that the emphasis on the Veda, regarded by prominent priests of contemporary Chidambaram as the authoritative source of "Śaiva" ritual knowledge and praxis, does not merely amount to paying lip service to the atavistic and ultimate source of Brāhmanic legitimacy, but is due to complex historical dynamics that shaped the relationship between Śaivism and Smārta Brāhmaṇism over a long period of time in South India.

\section{Playtexts: Staging the Sacred Spectacle}

In the sacred scenario of Chidambaram, the festival time is certainly unique. It is during this particular time that the ancient texts framing the cultural history of Chidambaram become alive once again for a short, meticulously measured period of ten days, ${ }^{14}$ when they assume, as it were, a voice of their own. In this context, the Citsabheśotsavasütra emerges as the main "playtext" used by the priestly community to "stage" the festival spectacle. ${ }^{15}$ Yet, definite echoes of Aghoraśiva's Mahotsavavidhi and Mānikkavācakar's Tiruvempāvai also play a role in the festival performance and religious symbology. Whereas the former is the prerogative of the priestly class only, the latter represents a category of "playtext" available to all devotees. In what follows we will first characterize the three texts under discussion and individuate the elements of commonality and difference between them as well as related sources; we will then move on to describe the festival performance as it unfolds in the light of the Citsabheśotsavasūtra.

\section{Citsabheśotsavasūtra}

The Citsabheśotsavasütra, insofar as it belongs to the genre of utsavavidhis, was apparently composed for the purpose of its practical implementation in the festival scenario. In the opening verses, the content of the text is described as "the explanation of the great festival procedure" (citsabheśasya mahotsavavidhim vyākhyā) ${ }^{16}$ It undoubtedly constitutes a 
source of instruction for the priestly community guiding festive rituals and is indeed carefully followed by priests of the Chidambaram Natarāja temple during the Ārdrā Darśanam Mahotsava.

The Citsabheśotsavasūtra gives a detailed account of the radical transformation of space, and also the organization of time, which must be enacted for the purpose of the sacred spectacle. This includes a special choreography, that is, a demonstrably organized sequence of events and procession of actors performing their myth-embedded roles. As is the case with all utsavavidhis, the Citsabheśotsavasütra is mostly concerned with the transformation of the "outer space," which results in an enhanced visuality. The "outer space" is the space that extends beyond the limits of the temple courtyards. The most significant impact of the festival practice lies in the sacralization of space that is normally considered "profane." The relevant prescriptive accounts of the Citsabheśotsavasütra serve the purpose of temporarily imposing on the real world the "archetypical" structure of the mythical, in illo tempore sacred time and space.

In a manner analogous to other utsavavidhis, the Citsabheśotsavasūtra aims at creating outwardly visible impressions that serve as a trigger for the inner or spiritual eye. At the center of the festival is the act of seeing. The observer is given entry into a ritualized visuality characterized by suspended temporality. Insofar as he is enticed to participate in the sacred event unfolding before his eyes, the observer gains entry into the massive presence of monumental time. The Citsabheśotsavasütra can therefore be regarded as the visual text that is "read" during the festival. Situated within a framework of fluid interactions between the "textual" and "performed" dimensions, this manual becomes a category of "playtext" that crosses into the realm of performing arts. The text is in fact put into action through a display of spectacle that engages the proclivities of the senses, in particular the sense of sight. The utsavadarśana is the most powerful apprehension of the divine spectacle that can be experienced by a devotee (John 1977).

Outwardly the transformation of space occurs through the visual display of festival decorations. The Citsabheśotsavasūtra dedicates a few paragraphs to the list of festive decorations that should adorn the temple pavilions, the processional routes, and the purification of the ground (bhütaśuddhi). These rules are still followed today by temple officials. The shrines are adorned with stalks of banana trees, while burning torches 
and colorful flags add to the overall festive atmosphere. Beautiful light sculptures of Națarāja and Śivakāmasundarī decorate the temple courtyard. The purification of the ground is carried out by drawing kōlam, the auspicious designs that are drawn using colorful powders. The temple interiors resound with the recitation of the Vedas and the Upanișads performed for six hours daily by panditas who have come to Chidambaram from different corners of India for the occasion. This detail matches textual injunctions that place a special emphasis on Vedic recitations (vedaghoșa or brahmaghoṣa). Equally important to the establishment of the festive space is the presence of the temple orchestra appointed to accompany the gods taking part in the procession. The orchestra consists of six musicians and a conductor playing the drum beats (nādasvara) in a special rhythm called nāndìtāla. There are also different groups of professional musicians who perform every night as well as little girls dancing bharatanattyam in the temple courtyards. The festival manuals make specific references to the enjoyment (vinoda) accompanying festival celebration produced by the triune of vocal music, instrumental music, and dance (tauryatrika). ${ }^{17}$ Such injunctions remind us of the patronage accorded by the Cōlas to singers, musicians and dancers, whose arts became extensively cultivated during the medieval period. It may be argued that the stress put on entertaining performances by the festival manuals reflected a widespread trend shaping the aesthetics of festival practices in medieval Chidambaram.

\section{Mahotsavavidhi}

The Mahotsavavidhi is part of Aghoraśiva's ritual manual entitled Kriyākramadyotik $\bar{a},{ }^{18}$ which is believed to shape the outlook of temple ritual acts in Tamilnadu to this day. Aghoraśiva, who lived in Chidambaram in the twelfth century, was one of the most influential exponents of the Sanskritic Śaiva Siddhānta and a prolific commentator on Saiddhāntika Āgamas. He shared with Oțtakkūtar royal affiliation with the Cōlas and especially with the Chidambaram Națarāja temple. According to Davis, in one of his works Aghoraśiva refers to himself as "a teacher who adorns the Chola region" (2010: 21). Aghoraśiva's presence in Chidambaram is a well-established fact. References to Chidambaram Śiva (Națarāja) are made in the Kriyākramadyotika as well as in his commentary on Sadyojyotis' Tattvasangraha. Moreover, as Whitney M. Cox (2006) observes, 
a contemporary tradition of Gotrasantati ("lineage of the teachers") acknowledges Aghoraśiva as the founder of the monastery (matha) on the outskirts of Chidambaram that received pious attention from the Cōla rulers. Given Aghoraśiva's widespread popularity and his unquestionable impact on the codification of temple practices in the Cōla region, it seems plausible to hold that the festival injunctions narrated in his Mahotsavavidhi enjoyed a similarly high status in temple circles.

An argument in support of this view is the striking similarity between the Mahotsavavidhi and the Citsabheśotsavasūtra with regard to the general pattern of the festival praxis. When compared through the medium of the festival performance itself, it seems that these two texts confront each other and view one another in a mirror of reciprocal reflections establishing a common framework of the systematic festival structure. A careful investigation of both texts uncovers a large area of commonality, but also shows that certain themes receive greater emphasis in either one text or the other. Some of the themes analyzed in these texts are in their turn missing from the contemporary festival space of Chidambaram, such as the "Great Festival of Śivakāmasundarī" (śrīśivakāmasundarìmahotsava). The exact opposite also occurs. For example, the most important event of the festival in contemporary Chidambaram, the royal audience of Națarāja and Śivakāmasundarī in Rāja Sabhā, is not even mentioned in the texts investigated here.

\section{Tiruvempāvai}

The Ārdrā Darśanam Mahotsava is also a festival of the bhakti tradition and finds its most eminent representative in the ninth-century Tamil saint Mānikkavācakar. During the ten days of the festival, the icon of Mānikkavācakar appears daily in front of Națarāja in the sancta sanctorum or "Hall of Consciousness" (citsabhā), where he receives worship. Singing of the Tiruvempāvai, Mānikkavācakar's devotional hymn, is a regular practice performed by devotees every evening during the ten days of the mahotsava. This brings forth a different performative emphasis. The singing of Tamil bhakti poetry, known as the "Tamil Veda," is normally the prerogative of a specific group of non-Brahmin singers, the otuvars. Indira V. Peterson claims that

the Tamil Śaiva audience perceives the otuvar as a medium, in a certain 
sense, a mediator between the text and itself....Listeners more often speak of "a moving rendering" than of "a great singer." In such a view, the otuvar is seen as a "good" performer when the audience feels that... through a "moving" rendering, he has revealed hidden meanings and subtle beauties in the saints' hymns that are by reputation beautiful and rich in devotional hymns (1991: 74).

The effectiveness of the otuvar lies, therefore, in his capacity to transfer the audience into devotional mood. The otuvar mediates between the audience and the author of the hymn by encoding the relationship between god, audience, and saint. The otuvar, thus, is an important means of conjuring up the presence of deity through "rhetoric of bhakti" (Cutler 1987: 51). Norman Cutler argues that the "rhetoric of bhakti" inherent in the hymns is conducive of generating a special kind of communication between the author of the hymn and audience which is, at the same time, a form of communion between devotee and god. Therefore, "through an all-consuming enjoyment of the sacred hymns, one experiences bhakti, and the experience of bhakti itself transforms the experiencer" (Cutler 1987: 51).

Here the "playtext" is "a dynamically constituted text" in the sense that its textual discourse is directly applied to the event of action, becoming the engaged practice. Singing the verses of the Tiruvempa avai is equal to performing an act of devotion that mostly affects the inner space of feelings and emotions. In the words of Cutler:

Bhakti poems are comparable to the script of a play in that the verbal document is only one aspect of a total performance situation. Just as an adequate poetics of the drama must take into account the relationships a play establishes among characters, actors, and audience members within a fictive theatrical reality, similarly, a poetics of bhakti must take into account not only the words of a bhakti poem but also the entire context in which it is recited. One might even claim that bhakti poetry is more intimately connected with the context of its performance than a script for a play. This is because the internal rhetorical structure of a model bhakti poem is actually projected onto the context of its performance. More specifically, the triangular relationship of poet, god, and audience that is encoded in the texts of these poems is 
embodied in the context of their performance....

All who participate in the ritual performance of the saint's poem reenact the saint's experience of communion with the deity (1987: 112-13).

In this context, the Tiruvempāvai emerges as the category of playtext in which the very act of recitation places the devotee in relationship to god through a verbal replication of the poet's religious experience narrated in this text. The textual fabric of the Tiruvempāvai is thus projected onto the context of performance, and it therefore becomes a means for spiritual exaltation. The experience of Mānikkavācakar becomes transmuted into the devotee-audience's experience, and in this way "the audience is brought into the kind of close proximity to divinity that distinguishes the saints from ordinary mortals" (Cutler 1987: 112). As a result, the fixed boundary between god, the saint, and the devotee-audience becomes blurred.

Singing of the Tiruvempāvai and other prominent hymns from the Tiruvācakam appears to have been a common practice during the Cọla regnum, as documented by several inscriptions dating back to the eleventh and twelfth century (Harris 2008: 111-12). As Anthony G. Harris argues, the Cōla kings utilized popular motifs and narratives, in particular those of Mānikkavācakar and other nāyañmārs, as a means to enhance both their political and religious status.

\section{Ārdrā Darśanam Mahotsava in Light of the Citsabheśotsavasūtra}

The sequence of the festival events, as well as its exact time and location, is published each year by the governing board of the temple. Most of the priest families have established trusts that publish an invitation to the festival with details of the entire program. The two days before the beginning of the actual festival are dedicated to the preliminary pujjas meant for an auspicious beginning, that is: nakșatra-pūjā, Ganeśa-pūja (devoted to the elephant God in his form of vighneśa, or "remover of obstacles"), vastuśānti-pūjā (meant for appeasement of the surrounding environment), and nāndī-śraddhā, the "bull ceremony." The Citsabheśotsavasūtra dedicates a lengthy passage to the establishment of temporary ritual constructions (yāgaśāla) and oblation places (balipītha). ${ }^{19}$ Another interesting 
preliminary rite carefully described in our text and still enacted today is the sowing of nine types of seeds in an earthen pot (ánkurārpana) which is believed to ensure the auspiciousness of the entire festival. Yet another mandatory rite prescribed in the Citsabheśotsavasütra is the tying of a protective cord (raksabandhana) around the wrist. This ritual ensures the safety of the head priest of the festival (ācarrya) who is responsible for the entire festive spectacle. The high status of the head priest is clearly acknowledged in the festival scenario. The head priest of the festival is identified with Siva himself, who is thereby also taken in procession. This is known as the "Festival of the Priest" (äcäryotsava). The priest is lifted onto the palanquin, shaded by a royal parasol and fanned with yaktails just like gods in their daily procession. A honorarium (daksinga $)$ is also given to him. Accompanied by musicians and devotees, he moves through the streets and stops from time-to-time to be garlanded by the greeting crowds. Davis remarks that the $\bar{a} c \bar{a} r y a-p \bar{j} j \bar{a}$, also called $\bar{a} c \bar{a} r y o t-$ sava, can be traced back to Vedic sacrifices where dakșina for the officiating priest involved "cows, land, gold, jewels, cloth and other valuables" (2010: 123). Interestingly, no ācāryotsava is mentioned in the Citsabheśotsavasūtra. On the other hand, the Mahotsavavidhi is fully aware of its significance.

In the year 2012, the actual festival began on December 19 at 6:00 a.m. with the raising of the flag on the flagpole (dhvajärohana) that stands between the Kanaka Sabhā and Nrtta Sabhā. This is a powerful and dramatic moment accompanied by recitations of the mantras and the sounds of drums. The images of the five deities (pañcamūrti)—Śiva in his form of Somāskanda, his wife Pārvatī, his two sons Murukan and Gaṇeśa, and his beloved devotee Caṇ̣eśa, who will be taken in procession over the following days-also arrive to celebrate this auspicious moment. The festival flag (dhvaja) that is hoisted on the flagpole receives a detailed description in our text. The flag banner features the bull Nandin, painted in red on white cloth. A parasol-the symbol of royal sovereignty par excellence-above Nandin's head, a trident (triśūla) and drums are also pictured on the flag. The text clearly declares that Nandin should be established on the flag-cloth (vrsapratiștha $)$ by the infusion of breath into the image (prānapratisțhā). ${ }^{20}$ The establishment of the bull on the flag (dhvajapata) is an elaborate ritual involving the preparation of a sacrificial platform (sthandila) in front of the bull and the drawing of a lotus with 
nine petals in the middle of it. The priest is then instructed to set up nine pots, one in the middle and the remaining eight in eight directions. ${ }^{21}$ The central pot should contain the five products of the cow (pañcagavya)milk, yoghurt, $g h \bar{l}$, urine and dung-mixed together; the resulting compound should be sprinkled on the flag accompanied by the recitation of the vrșa bijamantra. The invocation of the bull on the flag takes place through the ritual of prānapratișthā accompanied by the recitation of the vrșa bijamantra and the making of offerings. Equally important to the successful accomplishment of vrṣapratiștha $\bar{a}$ is the invocation of the King of Weapons (astrarāja), who should be visualized (dhyāna) as a terrifying figure with "three eyes, four arms, long ears, mounted on the bull accompanied by a deer, weapons, and a trident whose three spikes sym-

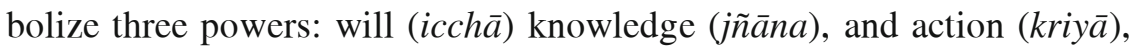
respectively." ${ }^{22}$ The raising of the flag concludes with the invocation of all deities that give benediction ( $\bar{a}$ sì $r v a \bar{d} d a$ ) for the festival.

Another inaugural ceremony to which both the Mahotsavavidhi and the Citsabheśotsavasūtra devote special attention is a drum ceremony (bherītādana) or beating the bheri drum. This is basically a consecration of the musical instruments that will accompany the gods going in procession. The inaugural musical concert played in the specific rhythm nāndìtāla is believed to bring about the ritual ordering of space. It is accompanied by priests chanting the hymns to the gods of the nine directions: Brahmā, Indra, Agni, Yama, Nṛtti, Varuṇa, Vāyu, Soma, and Ísaana. In accordance with textual descriptions, the drum ceremony constitutes an invitation to all deities and all living beings to attend the festival. Parameśvara Dīkșita confirmed the purpose given in the texts, but added that the drum ceremony is also enacted to ward off death for humanity. Although no textual reference that could confirm his statement is found in the Citsabheśotsavasūtra, the Mahotsavavidhikrama Ägamaśekhara by seventeenth-century Śaiva exegete Kacchapeśvara states that "by hearing these sounds the world is freed from all faults." In another passage, the same text asserts that the bheri-drum rite is enacted to protect all living creatures and for a general well-being of the world. ${ }^{23}$

The most characteristic feature of the festival practice is the moving of the festival icons of the deity (utsavamürti) to the public space outside of the temple compound. This dramatic movement of the deity from the sacred to the profane space is constituted by a procession of the five deities 
mounted atop different vehicles (vähana), such as goose, bull and elephant, or on chariots. The etymology of the word "vāhana," derived from the Sanskrit verbal root vah, "to carry," "to draw a cart," "to guide horses," and so on, is the best clue to its meaning used in the sense of transportation. In religious literature, vāhanas of gods were elevated to the position of mediators between the human and divine realms. For this reason, as Waghorne (1991: 26) reminds us, vāhanas were considered to go back and forth expanding divine power to the human world and communicate human things to the divine world. The processional icons of the deities dressed in festive clothes, beautifully ornamented and given offerings of incense, lamps and food, proceed in order (yātrākrama). ${ }^{24}$ The text mentions the evening procession that is carried out after 10:00 p.m. In Chidambaram, the actual order of the procession as well as the set of $v \bar{a} h a n a s$ exactly matches the scriptural injunctions given in the Citsabhesotsavasütra. Thus, the following six days are marked by the procession of Ganeśa riding atop a rat, Murukan on a peacock, Caṇ̣eśa on a bull, and Pārvatī on a goose (besides the goose, the Citsabheśotsavasūtra also prescribes a lion and a god as suitable vāhanas for the goddess). As to the main deity, Śiva in his popular form of Somāskanda, the text prescribes the Moon (candra) on the second day, Sun (sürya) on the third day, Demon (bhüta) on the fourth day, Bull (vrșabha) on the fifth day, Elephant (gaja) on the sixth day, and Kailāsa on the seventh day of the festival. The list tallies exactly with the schedule given in the Citsabheśotsavasūtra. ${ }^{25} \mathrm{On}$ the eighth day, our text prescribes the horse chariot (vāji-vāhana), which in the actual festival scenario is enacted as the procession of Bhikṣātana on a golden chariot pulled by two horses. The seventh and the eighth day of the festival are dedicated to the re-enactment of mythological stories, fueling the imagination of the people. Kailāsa-vāhana commemorates the immemorial myth of Rāvana lifting Mount Kailāsa, the abode of Śiva that resulted in his being trapped beneath the mountain by Siva himself for hundreds of years. In the contemporary festival scenario, Kailāsavăhana is the only procession that takes place twice, in the morning and again in the evening. Another actor who enjoys considerable fame is Bhikṣațana, Siva in the form of beggar, who commemorates the legends associated with Śiva's and Viṣnu's trip through Dārukā Forest in the guise of Bhikṣātana and Mohinī, respectively. ${ }^{26}$ As James L. Martin put it beautifully: 
Certain festival practices that are re-enactments of episodes from stories of gods are what [Mircea] Eliade would call "the eternal return." They are not based upon history but refer to the divine acts which establish and continue the factors which figure importantly in life itself. Thus, they are a return to and a participation in the primordial acts which give life meaning....The annually re-enacted dramas of these heavenly acts both reaffirm the devotees' acceptance of their changeless meaning and renew their reality (1982: 67-68).

The pinnacle of the festival takes place on the ninth and tenth day. The intensity increases dramatically, for it is at this auspicious time that the image of Națarāja from the central shrine (citsabhā) is taken in procession in a chariot (rathayātrā) according to textual prescription. These chariots, known in Tamil as têr, are wooden structures of gigantic size, ornamented with carved reliefs portraying animal and human figures. The festival event is the only time of the year when such chariots are set in motion, circling the public sphere around the temple. A pavilion hosting a deity is placed on a lavishly decorated chariot, which has previously been consecrated by the ritual imposition of several deities onto its various parts (rathanyāsa). When the procession is underway, the devotees pull the chariot along the streets in a clockwise direction (pradaksina) accompanied by music, dance, singing, and ritual offerings (Michell 1991). All five deities thus placed on their own chariots circumambulate the city following the chariot streets (rathamārga).

The Citsabheśotsavasūtra gives a detailed list of the participants who should accompany gods in the chariot procession. This list is interesting insofar as it gives us a glimpse of the social structure of Chidambaram during the "mythic" time of the text's composition. It provides us with the ordered sequence of participants that should follow Natarāja on the chariot. The first in line are musicians playing bherī drums, kettle drums, double-headed drums, and bass drums. Immediately after these come people holding a flag, a parasol canopy, and yak-tails- "the familiar Indic insignia of royalty" (Davis 2010: 31). These are followed by the devotees. The chariot carrying Ganeśa should proceed on the right side, while the one transporting Murukan should proceed on the left. After them come musicians playing instruments including the lute, flute, and cymbals. These must be in close proximity to the troupes of performers 
(ganikājana) in a state of playfulness, dancing, and singing. ${ }^{27}$ The next in line are royalty (rājādhikārapurusa) and devotees of Siva. The description given in the Citsabheśotsavasūtra makes a clear distinction between royalty and devotees of Siva. This distinction is enacted through the prescription that people holding burning torches and flower garlands should go in procession between these two groups. ${ }^{28}$ Equally interesting is the list of actors going in procession in front of Natarāja. First in line is a group of people carrying lavishly decorated vessels filled with incense (dhüpapātra) and lamps (dīpapātra); then comes the temple priests (ācārya), probably Smārta Brahmins of the Chidambaram temple, and sacrificial priests (rtvij), always referred to in the plural form, probably assisting priests of the festival. ${ }^{29}$ The officiating priest resides on the platform on the right side of Natarāja, while on the left side of the Lord, the divine power is placed. What becomes immediately clear from the above description is the high social status of the Chidambaram temple priests who are the only "actors" allowed to go in procession in front of Națarāja.

Behind Națarāja comes his beloved devotee Caṇdeśvara, accompanied by devotees and dance-servants (nrttasevaka). The latter group reminds us once again of the important role that ritual dance once played-and continues to play-in the Chidambaram temple. Immediately after come the "intellectuals": those learned in the Vedas, eminent Brahmins learned in all scriptures, and then the entire Brahmin community. Two categories of devotees, namely, those who possess knowledge of Siva and those who are engaged in Śaiva practice, form the next group. The text gives us a hint of the two main Śaiva traditions that existed in those times, namely, the Viraśaivas or Lingāyats, "those who carry a linga," referred to here as the lingadhärins, and the Pāsupatas, described as naked ascetics with twisted locks of hair (jatā), covered with ashes, and holding the rosary (rudrākșa). The procession march ends with Tamil speakers (drāvidabhāssāprācarapurușa), old people, and reciters of religious hymns. The Citsabheśotsavasūtra offers a joyful image of festive celebration, in which participants are engaged in lively stir, dancing, singing, and playing. ${ }^{30}$ Upon the completion of rathaya $\bar{t}$ tra , the deities re-enter the temple pavilion called Rāja Sabhā. The Rāja Sabhā, the royal hall, known also as the Thousand Pillars Hall, was built during the Cōla reign for the purpose of royal coronation. In the pre-dawn hours of the tenth day under the full moon, ritual ablution (abhișeka) is performed on Națarāja on the steps of 
the Rāja Sabhā, which is followed by a royal audience (darśana) of Națarāja and Śivakāmasundarī at the same venue. In medieval India, the rājyābhișeka ceremony literally marked the "ritual installation into kingship" and was, therefore, one of the most significant "royal rituals" (räjakarma) (see Inden 1998: 52-82). This most important "moment" of the entire festival, with its eminently royal character, is not even mentioned in the Citsabheśotsavasütra. To explain this fact, Younger (1995: 74) reasserts the hypothesis that the royal audience does not require any specific ritual functions that the priests must necessarily carry out, hence the omission in the festival manual. However, even though the Citsabheśotsavasūtra does not provide any details regarding the royal audience, it does dedicate a lengthy passage to the ritual ablution (mahäbhiseka) that specifically requires the presence of priests performing a ritual function. ${ }^{31}$ In view of this, Younger's argument cannot be held valid.

The "Festival of Black Paste" (krșnagandhotsava), a famous Āgamic ritual still enacted during Chidambaram festival, ${ }^{32}$ receives some attention in the Citsabheśotsavasūtra. Perhaps this ritual has been incorporated into the "Vedic" repertoire of the Citsabheśotsavasūtra because of its popularity in the temples that follow the Śaiva Saiddhāntika canon. The krṣnagandhadhärana is part of the chariot procession (rathayātrā). In describing this ritual, the text concentrates mainly on the ritualistic preparation of black paste that should involve, among other things, the infusion of the paste with mantric power by reciting the pañcākșara mūlamantra, probably "(om) na-mah sí-vā-ya," and the five brahmamantras. ${ }^{33}$ The Citsabheśotsavasutra states briefly that the ritual application of black paste on the icons of Națarāja and Śivakāmasundarī should come after smearing them with fresh butter. Afterwards, the icons of the deities should be dressed in white clothes. Our text does not provide any details regarding the ingredients used in the preparation of black paste. However, the Dîkșitas informed me about a decoction, called yakșardama, "the mud of the Yakșas," which, according to the Sanskrit lexicon Amarakośa, is a mixture of agallochum, sandal, camphor, musk, and kākolla berries. ${ }^{34}$ Neither does the Citsabheśotsavasütra give any philosophical explanation of this festival ritual. The text simply declares its ritual efficiency in bringing to fruition all wishes and desires in connection with four human goals (purușārtha), namely, dharma, kāma, ārtha and mokșa. ${ }^{35}$ On the other hand, the Saiddhāntika Kāraṇāgama connects krṣnagandhotsava 
with Śiva's act of concealment (tirodhāna). The text says that black paste represents the three fetters (mala) of kārma, māyizya, and ānavamala that, according to Saiddhāntika theology, bind the human soul. These impurities should be offered to Siva Națarāja who, smeared with the black paste and cleansed of it, enacts the removal of concealment that "covers" the soul (Davis 2010: 129).

Table 1: Festival Events During the Ārdrā Darśanam Mahotsava in 2012

\begin{tabular}{|c|c|}
\hline $\begin{array}{l}\text { First Day: } \\
\text { December } 19\end{array}$ & $\begin{array}{l}\text { Morning: The flag-raising on the flagpole } \\
\text { (dhvajārohana }) \\
\text { Evening: A drum ceremony (bherītādaṇa) }\end{array}$ \\
\hline $\begin{array}{l}\text { Second Day: } \\
\text { December } 20\end{array}$ & $\begin{array}{l}\text { Night: Procession of the deities (yātrākrama): } \\
\text { Gaṇeśa on a rat, Murukan on a peacock, Caṇdeśa } \\
\text { on a bull, Pārvatī on a goose. } \\
\text { Somāskanda on the candra-vāhana }\end{array}$ \\
\hline $\begin{array}{l}\text { Third Day: } \\
\text { December } 21\end{array}$ & $\begin{array}{l}\text { Night: Procession of the deities } \\
\text { Somāskanda on the sūrya-vāhana }\end{array}$ \\
\hline $\begin{array}{l}\text { Fourth Day: } \\
\text { December } 22\end{array}$ & $\begin{array}{l}\text { Night: Procession of the deities } \\
\text { Somāskanda on the bhüta-vāhana }\end{array}$ \\
\hline $\begin{array}{l}\text { Fifth Day: } \\
\text { December } 23\end{array}$ & $\begin{array}{l}\text { Night: Procession of the deities } \\
\text { Somāskanda on the vrșabha-vāhana }\end{array}$ \\
\hline $\begin{array}{l}\text { Sixth Day: } \\
\text { December } 24\end{array}$ & $\begin{array}{l}\text { Night: Procession of the deities } \\
\text { Somāskanda on the gaja-vāhana }\end{array}$ \\
\hline $\begin{array}{l}\text { Seventh Day: } \\
\text { December } 25\end{array}$ & $\begin{array}{l}\text { Morning / Evening: Procession of the deities } \\
\text { Somāskanda on the Kailāsa-vāhana }\end{array}$ \\
\hline $\begin{array}{l}\text { Eighth Day: } \\
\text { December } 26\end{array}$ & $\begin{array}{l}\text { Evening: Procession of Bhikșātana on the vāji- } \\
\text { vāhana }\end{array}$ \\
\hline $\begin{array}{l}\text { Ninth Day: } \\
\text { December } 27\end{array}$ & $\begin{array}{l}\text { Morning: Procession of the deities in chariots } \\
\quad(\text { rathayātrā) } \\
\text { The "Festival of Black Paste" (krṣnagandhotsava) }\end{array}$ \\
\hline $\begin{array}{l}\text { Tenth Day: } \\
\text { December } 28\end{array}$ & $\begin{array}{l}\text { At 3:00 a.m. Ārdrā Darśanam: The royal audience of } \\
\text { Națarāja and Śivakāmasundarī in the Royal } \\
\text { Coronation Hall (rājasabhā) } \\
\text { Afternoon: The flag-lowering ceremony } \\
\text { (dhvajāvarohana) }\end{array}$ \\
\hline
\end{tabular}


After the dismissal of the deities (devavisarjana), the final act of the sacred spectacle is the lowering of the flag ceremony (dhvajāvarohana) that takes place on the same day as the abhiseka, in the afternoon or in the evening. The festival is then officially concluded.

\section{Conclusion}

Textual research on the Sanskrit ritual manual Citsabheśotsavasūtra shows that this source is generally followed in a meticulous manner by the priestly community of Chidambaram during the staging of the Ārdrā Darśanam Mahotsava. Both the ritual and the underlying text appear to stem from the historical milieu of the Cōlas, who promoted religious festivals as the main cultural practice of their times. The Cōlas, conscious of the great impact of festival practice on the minds of their subjects, established patronage over the new literary genre of the utsavavidhis to meet their political ends. Even in the contemporary scenario, festival practice is predominantly shaped by political aesthetics and imagery, connected as it is with the celebration of "royal" gods giving audience (darśana) to the spectators-devotees. As suggested by the flourishing of the textual tradition of utsavavidhis, the Cōlas encouraged some kind of uniformity with regard to festival practice.

The Citsabheśotsavasūtra constitutes a fine example of a festival manual comprised of both "Vedic" and "Āgamic" elements. These seemingly contested religious and cultural paradigms were reconciled and reconfigured in the festival arena in such a way that ideological disparities were bridged and a feeling of common identity was produced. This led to the realization that, despite their different doctrinal predilections, the two traditions still shared the god and the king. The degree to which the "Āgamic" Mahotsavavidhi and the (predominantly) "Vedic" Citsabhe-śotsavasütra wereand still are-seen as similar and dissimilar is largely a matter of their differing emphasis. Both texts seem to belong to a cultural and historical milieu where festival practice was predominantly connected with the celebration of the city's local kingship and where the local rulers and eternal gods were worshiped side by side as the boundaries between them were fluid. At the center for this intricate amalgam of intertwined elements coming from Vedic and Āgamic Sanskrit cultures lies a great Tamil bhakti tradition, whose deep devotional aspect is embodied in the literary source 
Tiruvempa avvai as well as in the practice of the devotees on the festival stage. It is perhaps due to this strong and enduring "popular" dimension that the festival has survived through the centuries without any royal presence or participation.

The Chidambaram festival represents a complex and hybrid interplay of disparate discourses and processes. On the basis of the consistencies and inconsistencies between the "prescribed" and the "performed" dimensions of the festival, it is possible to claim that at some point in history the festival practice of Chidambaram, even if substantially following the procedure described in the Citsabheśotsavasūtra, underwent significant changes. To identify these changes and investigate the historical dynamics behind them remains a desideratum for future studies.

\section{Notes}

1. It is interesting to note that festivals (mahotsava) treated in the Vaiṣnava Pāñcarātra texts are also enacted to celebrate the "star-day of the temple-image" (Smith 1982: 29).

2. See, for example, Brunner (1975-76); Davis (1991); Smith (1998); Younger (2002).

3. Citsabheśotsavasūtra: Śrīcitsabheśamahotsavaprayogah, p.1.

4. Davis (2010) has studied this text in detail. Goodall (1998: xiii-xviii, n24) argues that Aghoraśiva's authorship of the Mahotsavavidhi is highly problematic given the fact that the text contains a large and heterogeneous body of materials from different sources. See also note 19 below.

5. For the list of different festivals performed on the occasion of king's asterism, see Swaminathan (1978).

6. "Ārdrā" is also known as "Ārudra," after the presiding deity of this asterism—Rudra—who symbolizes the cosmic act of destruction.

7. See Annual Report on South Indian Epigraphy for 1913, inscription number 104 (Swaminathan 1978: 272).

8. Kulke writes thus: "It is beyond doubt that the daily performance of rituals and the great annual festivals of the 'royal deities' - with all their royal paraphernalia and exuberant wealth-became the best and most visible legitimation of royal power and wealth of the 'divine kings' on the earth" " (1993: 11). For a critique of the "functionalist legitimation theory" that in large part undergirds Kulke's scholarship, see Cox (2006: 60-63). 
9. The Cōlas were associated with the tiger, the Cēras with the carp (see Sastri 1955: 11; Stein 1998: 136).

10. See Annual Report on South Indian Epigraphy for 1959, inscription number 314 (Orr 2004: 461).

11. See Brunner's (1980-81) discussion of the Āgamic statement "siddhānto vedasāras syāt," and similar ones, regarding Saiddhāntika Āgamas as the real essence of the Veda. This view individuates an opposition between the Vedas, defined as common scriptures (sāmānyaśāstra), and the Āgamas, defined as special scriptures (viśeșaśāstra); the latter purportedly reveal the "real meaning" of the Vedas.

12. It is most likely that there existed at least two Umapātis in medieval Tamilnadu. For a critique of Smith's attibution of the Kuñcitānghristava to the fourteenth-century Umapāti, see Nagaswamy (1998).

13. See, for example, the rules concerning the ablution of the bull, or vrṣasnapanavidhi (Citsabheśotsavasūtra, p.59).

14. It is important to note that both Citsabheśotsavasūtra and Mahotsavavidhi identify themselves as the ritual manuals meant for a nine-day festival.

15. According to G. Parameśvara Dīkșita, the entire festival practice in contemporary Chidambaram depends solely on the Citsabheśotsavasūtra.

16. Citsabheśotsavasūtra: Śrīcitsabheśamahotsavaprayogah, p.1.

17. Citsabheśotsavasūtra: Yātrākramah, p.189.

18. As Goodall (1998: xiii-xviii, n24) points out, the Mahotsavavidhi is a composite and heterogeneous compilation. According to Davis and Orr (2007: 74-75), the materials occurring at the end of Mahotsavavidhi can be identified as the Mahotsavavidhikrama Ägamaśekhara composed by seventeenth-century Śaiva exegete Kacchapeśvara. Neither the issue of whether the twelfth-century Aghoraśiva was the author of the Mahotsavavidhi, nor the actual date of the text (which must predate the seventeenth century), bear on the main argument exposed in this article.

19. Citsabheśotsavasūtra: Maṇdapapūjāvidhih, pp. 98-148.

20. Citsabheśotsavasūtra: Vṛ̦asnapanavidhih, p.59.

21. Citsabheśotsavasūtra: Dhvajasamprokșaṇasnapanapūjā, p.58.

22. Citsabheśotsavasūtra: Vrṣasnapanavidhih, p.61.

23. Mahotsavavidhikrama Āgamaśekhara, pp. 389-90, cited in Davis (2010: 88).

24. Citsabheśotsavasūtra: Yātrākramah, p.189. 
25. Citsabheśotsavasūtra: Yātrākramah, pp. 188-89.

26. A fine explanation of this myth is given in Shulman and Handelman (2004).

27. See, for example, the similar description of performers (rudraganikā) in the Mahotsavavidhi, related in Davis (2010: 45-46).

28. Citsabheśotsavasūtra: Yātrākramah, pp. 189-90.

29. According to Davis (2010: 44), Aghoraśiva often refers to rțvijs in the meaning of "assisting priests," who act as an "extension" of the head priest of the festival.

30. Citsabheśotsavasūtra: Yātrākramah, p.190.

31. It should be mentioned that the text dedicates a lengthy passage to the ritual procedure of mahābhiseka, see Citsabheśotsavasūtra: Mahābhisekavidhih, pp. 230-32.

32. See the analysis by Nagaswamy (2003: 84-91).

33. Citsabheśotsavasūtra: Kṛ̣nagandhadhāranaprayogah, pp. 219-24.

34. Amarakośa 2.6.3.34, referred to in Davis (2010: 129).

35. Citsabheśotsavasūtra: Kṛ̣nagagandhadhāraṇaprayogah, p.218.

\section{References Cited}

Ali, Daud. 1996. "Regimes of Pleasure in Early India: A Genealogy of Practices at the Cola Court." Ph.D. Dissertation. Chicago: University of Chicago Library.

Bauman, Richard. 2012. "Performance." In Regina F. Bendix and Galit Hasan-Roken, eds., A Companion to Folklore, 94-118. London: WileyBlackwell.

Brunner, Hélène. 1975-76. "L'importance de la littérature âgamique pour l'étude des religions vivantes de l'Inde." Indologica Taurinensia 3-4: 107-24.

Brunner, Hélène. 1980-81. "Le Śaiva-Siddhānta, 'essence' du Veda (Étude d'un fragment du Kāmikāgama)." Indologica Taurinensia 8-9: 51-66.

Citsabheśotsavasūtra (by Bhagavan Patañjali). 1982. Citsabheśotsavasūtra. Volume 2: Cidambarakṣetrasarvasva (ed. Somasetu Dīkșita). Chidambaram: M.S. Trust.

Cox, Whitney M. 2006. "Making a Tantra in Medieval South India: The Mahārthamañjari and the Textual Culture of Cōla Chidambaram." Volume 1. Ph.D. Dissertation. Chicago: University of Chicago Library. 
Cutler, Norman. 1987. Songs of Experience: The Poetics of Tamil Devotion. Bloomington: Indiana University Press.

Davis, Richard H. 1991. Ritual in an Oscillating Universe: Worshiping Siva in Medieval India. Princeton: Princeton University Press.

Davis, Richard H. 2010. A Priest's Guide for the Great Festival: Aghorasiva's Mahotsavavidhi. New York: Oxford University Press.

Davis, Richard and Leslie Orr. 2007. "People of the Festival." In Dominic Goodall and André Padoux, eds., Mélanges tantriques à la mémoire d'Hélène Brunner, 73-98. Pondicherry: Institut français de Pondichéry.

Goodall, Dominic, ed. and trans. 1998. Bhațtarāmakanthaviracitā kiranavrttih: Bhațta Rāmakantha's Commentary on the Kiranatantra. Volume 1: Chapters 1-6. Pondicherry: Institut français de Pondichéry.

Harris, Anthony G. 2008. "Obtaining Grace: Locating the Origins of a Tamil Śaiva Precept.” Ph.D. Dissertation. Austin: University of Texas Library.

Inden, Ronald 1998 [1978]. "Ritual, Authority, and Cyclic Time in Hindu Kingship." In John F. Richards, ed., Kingship and Authority in South Asia, 41-91. Delhi: Oxford University Press.

Jacobsen, Knut A. 2006. "Hindu Processions, Diaspora and Religious Pluralism." In P. Pratap Kumar, ed., Religious Pluralism and Diaspora, 163-73. Leiden: Brill.

John, Stanley M. 1977. "Special Time, Special Power: The Fluidity of Power in a Popular Hindu Festival." Journal of Asian Studies 37, 1: 27-43.

Kulke, Hermann. 1993. Kings and Cults: State Formation and Legitimation in Indian and Southeast Asia. Delhi: Manohar.

Loud, A. John. 2004. Rituals of Chidambaram. Chennai: Institute of Asian Studies.

Mahotsavavidhi. 1910. Mahotsavavidhi (ed. Mayilai Alagappa Mudaliyar). Chennai: Sivajnanabodha Press.

Mahotsavavidhi. 1974. Mahotsavavidhi (ed. C. Swaminatha Gurukkal). Chennai: South Indian Archakar Association.

Martin, James L. 1982. "The Cycle of Festivals at Pārthsārathi Temple." In Guy R. Welbon and Glenn E. Yocum, eds., Religious Festivals in South India and Sri Lanka, 51-77. Delhi: Manohar.

Michell, George. 1991. "Chariot Panels from Tamil Nadu." Marg 43, 2: $30-52$. 
Nagaswamy, R. 1998. "Eastern Indian Contact with Tamilnad." Journal of Bengal Art 3: 33-47.

Nagaswamy, R. 2003. Facets of South Indian Art and Architecture. Volume 1. Delhi: Aryan Books International.

Orr, Leslie. 2004. "Processions in the Medieval South Indian Temple: Sociology, Sovereignty and Soteriology." In Jean-Luc Chevillard, ed., South-Indian Horizons: Felicitation Volume for François Gros on the Occasion of his 70th Birthday, 437-70. Pondicherry: Institut français de Pondichéry.

Peterson, Indira V. 1991 [1989]. Poems to Siva: The Hymns of the Tamil Saints. Delhi: Motilal Banarsidass.

Pollock, Sheldon. 1985. "The Theory of Practice and the Practice of Theory in Indian Intellectual History." Journal of the American Oriental Society 105, 3: 499-519.

Sastri, Nilkantha K. A. 1955 [1935, volume 1; 1937, volume 2]. The Côlas. Madras: University of Madras.

Shulman, David and Don Handelman. 2004. Siva in the Forest of Pines: An Essay on Sorcery and Self-Knowledge. Delhi: Oxford University Press.

Smith, David. 1998 [1996]. The Dance of Siva: Religion, Art and Poetry in South India. Delhi: Foundation Book.

Smith, H. Daniel. 1982. "Festivals in Pañcarātra Literature." In Guy R. Welbon and Glenn E. Yocum, eds., Religious Festivals in South India and Sri Lanka, 27-50. Delhi: Manohar.

Stein, Burton. 1998. "All the King's Mana: Perspectives on Kingship in Medieval South India." In John F. Richards, ed., Kingship and Authority in South Asia, 133-88. Delhi: Oxford University Press.

Swaminathan, A. 1978. "Festivals After the Asterism of the Chola Kings." In, Proceedings of the Indian Historical Congress, 39th Session, Osmania University, Hyderabad, 270-74. Delhi: Indian History Congress.

Waghorne, Joanne Punzo. 1991. "Vāhanas: Conveyors of the Gods." Marg 43, 2: 15-28.

Waghorne, Joanne Punzo. 1999. "Chariots of the God/s: Riding the Line between Hindu and Christian." History of Religions 39, 2: 95-116.

Wentworth, Blake Tucker. 2011. Yearning for a Dreamed Real: The Procession of the Lord in Tamil Ulās. Ph.D. Dissertation. Chicago: University of Chicago Library. 
Younger, Paul. 1995. The Home of Dancing Sivan: The Traditions of the Hindu Temple in Citamparam. New York: Oxford University Press.

Younger, Paul. 2002. Playing Host to Deity: Festival Religion in the South Indian Tradition. New York: Oxford University Press.

ALEKSANDRA WENTA is a fellow at the Indian Institute of Advanced Study, Shimla, Himachal Pradesh, India.

alexandrawenta@gmail.com 